\title{
Primary Intraosseous Squamous Cell Carcinoma-Solid Type
}

National Cancer Institute

\section{Source}

National Cancer Institute. Primary Intraosseous Squamous Cell Carcinoma-Solid Type. NCI Thesaurus. Code C7491.

A non-keratinizing or keratinizing squamous cell carcinoma that arises centrally from the jaw. It is characterized by a solid pattern, infiltration of the marrow spaces, and osseous resorption. 